\title{
INDONESIA DIGITAL ECONOMIC DIPLOMACY DURING THE COVID-19 GLOBAL PANDEMIC
}

\author{
Dewi Triwahyuni \\ Department of International Relations, Universitas Komputer Indonesia, Bandung, Indonesia
}

\begin{abstract}
The study aims to optimize the use of Information Technology in Indonesian diplomacy during the COVID-19 pandemic, especially in the economic sector. To analyze this phenomenon, the research uses qualitative methods. The study is analytical descriptive by collecting detailed data from various sources of information, especially from multiple sources related to the object of this study. The research results concluded that Indonesia does not have a clear agenda or blueprint for using digital diplomacy. Because the use of information technology to publish policies during the COVID-19 pandemic is increasing, Indonesia must continue to learn from many countries in introducing the formulation of an economic digital diplomacy agenda from institutional adaptation to new approaches in foreign policy socialization through new media. This research will impact a more comprehensive digital diplomacy model for Indonesia.
\end{abstract}

Keywords: Digital Diplomacy, National Interest, COVID-19 Global Pandemic, Indonesia, Economic

DOI: http://dx.doi.org/10.15549/jeecar.v9i1.880

\section{INTRODUCTION}

Indonesia's economic digital diplomacy is entering a phase full of challenges during this COVID-19 pandemic. Although Indonesia has begun implementing digital diplomacy to achieve national interests, it has not yet achieved maximum results. This pandemic has forced Indonesia to change its diplomacy, especially in the economic field.

Countries must formulate public diplomacy strategies to achieve national interests in the current global political conditions in facing global changes. Therefore, it is essential to consider the competent political performance of actors, both state and non-state actors interacting in the international system (Bejola et al., 2015).
In the practice of diplomacy, there are several main functions. First, diplomacy is a tool for communicating between countries. Second, diplomacy serves to negotiate agreements. The third is the intelligence function, which is how to collect various information from foreign countries for their countries. Fourth, to avoid or minimize friction in international relations, the last function is to symbolize the existence of the nation's people (Bull, 2002).

Diplomacy has evolved constantly throughout the centuries from wars to peace treaties, invasions to summits, and even Twitter town halls and tweetups. However, its evolution is more evident in the tools used and its focus and priorities than in its definition and core aspects. War has changed, as well as are its tools. Both war and diplomacy still relate to - how states 
interact with each other; how they negotiate deals; how they regulate their relations with outside entities, mostly other sovereign states; how they survive through a set of laws and conventions, of which the diplomatic corps and the military are usually the most well-known and elitist appendices (Sandre, 2015).

Digital diplomacy can encourage the creation of economic cooperation. Currently, no country is immune to global economic megatrends, such as rising inequality, the impact of the 4th industrial revolution, and recent trade tensions between several countries. As a result, diplomacy and cooperation are the only ways to deal with these challenges.

Digital diplomacy can provide another potential in using technology media besides video conferencing. In this case, diplomats are required to get used to using other media, such as social media or video blogs to be able to communicate with fellow diplomats and the public. The Ministry of Foreign Affairs and diplomats are also required to be able to combine traditional and digital diplomacy practices. In the era of the pandemic, the government can communicate with the public by holding a question-and-answer session that can be done via social media applications such as Facebook for example.

There is a clear distinction between the use of digital tools in the activities of diplomats or the Ministry of Foreign Affairs and the implementation of diplomacy in cyberspace. The use of digital tools is better known as ediplomacy, which is an effort to use technology and social media for diplomats and consular duties (Barrinha and Renard, 2017).

Fletcher revealed that e-diplomacy was formally came out in 1994. That is when the Swedish prime minister made the wrong decision. He sent congratulations via e-mail to United States President Bill Clinton for his decision to lift the embargo on Vietnam (Fletcher, 2016). The debate on the new model of diplomacy is currently dominated by the increasing level of dependence on technology to fulfill diplomatic tasks (Copeland, 2015). This causes some expert opinions to see the necessary adaptation to this technology as a crucial aspect in guaranteeing the dominance of state power in a world situation that is increasingly connected to each other (Hocking and Melissen, 2015).

Cyber-diplomacy is a concept that has not been studied long enough. Therefore, many people misunderstand it and equate it with the idea of "e-diplomacy." In the article "The Origin of Digital Diplomacy," Dizard explains at least three important roles that diplomacy plays in the information age. First, raise issues about foreign policy involving sources of information and communication using advanced technology. Second, various changes in information sources within the ministry of foreign affairs and bureaus related to foreign policy. Third, the surge in the role of public diplomacy, especially those using digital technology in influencing public opinion. The three points above are critical to underline in measuring the influence of foreign policy on the development of information technology (Yahya, 2016).

Cyber and digital diplomacy are often used interchangeably but are fundamentally different. Digital diplomacy refers to the wider use of technology, particularly the internet and other Information and Communications Technology (ICT)-based innovations, in conducting diplomacy. Meanwhile, cyber diplomacy refers to diplomatic strategies used in dealing with issues, such as security, that arise in cyberspace. Therefore, digital diplomacy has been closely related to public diplomacy efforts by countries. However, digital diplomacy is more than just public diplomacy. The Information and Communications Technology (ICT) development in international relations has encouraged many scholars to research it. Several previous studies examining related themes will be described below.

The first previous studies are highlighted the massive changes in diplomacy during the pandemic was carried out by Sharma and Sisodia (2021). They highlighted the shift of communication channels during COVID-19. They said that before the global pandemic, the government's awareness of the role of diplomacy was deficient. However, this research only focuses on digital platforms on Twitter and Facebook (Sharma and Sisodia, 2021).

Other studies also explain that digital diplomacy is a new development, especially in international relations. Digital diplomacy is considered a breakthrough because it can change behavior and influence the thoughts and beliefs of other parties without having to use violence such as invasions or through war. Conversely, to influence public opinion, image and create social 
change can be achieved by using information and communication technology such as social media platforms (Asadi, 2017).

The two studies above have illustrated how diplomacy has accepted the challenges of Information and Communications Technology (ICT) change. However, both have not explained how the tragedy of the COVID-19 pandemic has accelerated this change. Furthermore, several other studies explain the digital diplomacy theme that takes place during the global COVID19 pandemic.

A study explains how practical bilateral and multilateral relations are in this pandemic. All the convenience offered in digital communication automatically reduces the operational costs of communication activities and various other diplomacy activities. (Purwasito and Kartinawati, 2020). Another study said that the trend of cyberspace as a place for diplomacy provides greater space for the role of sub-state actors. In this case, External Affairs see the effectiveness of paradiplomacy in various foreign affairs (Luerdi, 2021).

The three studies above explain the impact of the global COVID-19 pandemic on the practice of diplomacy. However, it has not explained how the impact will be on the national interest, especially in the economic sector. Moreover, only less research has been done related to digital diplomacy in the midst of a pandemic by choosing Indonesia as the research subject.

In contrast to previous studies, this research will focus on how the Indonesian state maximizes digital diplomacy for economic interests in the current global COVID-19 pandemic. Both globally and for Indonesia, this condition has two sides of a coin. Even though online diplomacy activities can reduce the budget for operations, a precise strategy is needed to maximize diplomacy digitally. Secondly, this research will emphasize digital diplomacy transformation must be formulated in a blueprint. Those two points above become the novelties of this research. The purpose of this study is to see how far Indonesia has optimized digital diplomacy to achieve its national economic interests, especially during the global COVID-19 pandemic.

\section{METHOD}

This research used a qualitative method and a descriptive analysis approach. The qualitative method was chosen as recommended in social and political science. On the other hand, a qualitative method in research is based on collecting, analysing, and interpreting data, the results of which will be in the form of narratives and visuals (not numbers). The descriptive approach is used to describe phenomena that occur in international relations.

Research in this method focuses on Indonesian economic digital diplomacy issues during the global COVID-19 pandemic. Research is focused on digital diplomacy, policies to achieve national economic interests. The process carried out in this study requires time and conditions to change so that the definitions presented in this study will change the research design and impact how to do it flexibly. Therefore, this research is qualitative with a descriptive-analytical research approach by collecting detailed data from various sources, especially from multiple sources related to the object of study in this study.

Literature study is a technique used in obtaining research data. Literature study is a method of solving problems by examining in depth the sources of writing made previously. Therefore, literary studies are often associated with the term literature studies. In the research to be carried out, of course, a researcher must have broad insight into the object to be studied. If not, the research will undoubtedly fail in a large presentation. Therefore, the researchers conducted a literature review from various journals to broaden the understanding of digital diplomacy and improve the analytical skills of the subjects to be studied in this research.

Referring to the problems raised by the study, the researchers conducted data analysis based on records and information issued by the Government of Indonesia, such as the Ministry of Foreign Affairs (MoFA) and the Indonesian embassies and consulates, to understand the diplomatic policies developed during the pandemic. Data from this institution is critical to understand what forms of digital diplomacy have been done by the Indonesian Ministry of Foreign Affairs, primarily since the COVID-19 pandemic occurred. Finally, the data was analyzed to see the urgency of its effect on Indonesia's economic sector. 
Data from the ministry of commerce is also an important source to see the economic interests that Indonesia is aiming for through its diplomacy. For comparison, data was also taken from research institutions, official news sites, various facilities such as book journals, and other documents.

\section{RESULTS AND DISCUSSION}

We live in a time of great paradox and transformational change in our society, economy, and environment. The COVID-19 pandemic hit during the so-called crisis of multilateralism. While global cooperation is most needed to reduce the spread of the virus and develop a vaccine, multilateralism has been portrayed in the media as slow to mobilize, lacking in political leadership, and disappointing to many. The repercussions were profound, with the tragic loss of life in the first few months of the pandemic due to an overwhelmed health care system. The socio-economic recovery is estimated to take at least four years to recover. Public health and multilateral diplomacy have come into the spotlight on the international stage (Alhashimi et al., 2021). The existence of COVID-19, which has become a global pandemic, has affected the economy. COVID-19 causes world economic growth to be in uncertainty. Six major trends in diplomatic practice caused by pandemic, namely: (1) acceleration of Information and Communications Technology (ICT) penetration; (2) reassessment of information security; (3) ensure reliability public diplomacy; (4) further diversification of responsibilities Duty; (5) increasing the role of psychology; and, (6) emergence of hybrid diplomatic ethics and protocols (Abduazimov, 2021).

The economy is one of the sectors most affected by the pandemic. The International Monetary Fund (IMF), the World Bank, and the World Economy Forum forecast the influence of the COVID-19 pandemic on the global economy. For example, the IMF predicts that the advanced country will experience a contraction in economic growth between $-5.5 \%$ to $-15.4 \%$ during the pandemic. And during the pandemic, the average economic growth was minus $10.7 \%$. While for emerging countries and middle countries, it is estimated that the contraction will be between $-4.8 \%$ to $-13.3 \%$ (IMF, 2021).

The current situation of the COVID-19 pandemic is indeed a challenge for economic diplomacy to encourage foreign investment into Indonesia. However, through their diplomatic efforts, Indonesian Representatives abroad, including the Indonesian Embassy in Beijing, are committed to maximizing Indonesia's economic growth opportunities in welcoming a new normal" era.

Currently, we see many countries using digital platforms or various kinds of social media to build a positive image and fulfill their foreign policy. Popular social media platforms used today include Facebook, Twitter, Instagram, YouTube, etc. Few representatives of countries abroad carry out their duties interactively through these social media platforms. The current trend of the global community prefers ambassadors who actively use social media in carrying out their functions as diplomats (Olubukola, 2017).

For Indonesia, digital diplomacy is considered essential to control problems concerning its citizens. The Indonesian Ministry of Foreign Affairs also gave special attention to this kind of diplomacy. For example, the ministry used a digital monitor to monitor Indonesian migrant workers in several countries (Syaifani and Adesina, 2017). Indonesian foreign minister Retno L. P. Marsudi mentioned four benefits of digital diplomacy. First, digital diplomacy can be utilized to disseminate peace messages. Second, it is an instrument to improve the economic partnership. Third, it is an instrument to protect citizens. Finally, it is also an instrument to advance development (Indonesia Ministry of Foreign Affairs, 2019).

Also, the pandemic has changed the paradigm in business. The pandemic has forced us to accelerate digital transformation in almost all sectors. The key to recovering from the economic downturn caused by this pandemic is adaptation and innovation. Diplomacy during a pandemic must be directed beyond just looking for opportunities and how to take advantage of these opportunities to realize real economic value for the benefit of the people.

Indonesia's awareness of the need for digital diplomacy in the face of Globalization 4.0 has been seen at least from some concrete actions taken. When Indonesia hosted the 2019 "The Regional Conference on Digital Diplomacy (RCDD)" meeting, several important points were agreed upon, which was later referred to as the 
"Jakarta Message." Among them is an agreement on cooperation and action plans between the government, the private sector, and other stakeholders to increase the use of digital technology in diplomacy. (Yasmin, 2019).

The COVID-19 pandemic has increased the importance of digitalization in achieving foreign policy. On November 16, 2021, Indonesia hosted the International Conference on Digital Diplomacy (ICDD) with the theme "Unmasking digital diplomacy in the new normal." Policymaking, including in foreign policy, has been hampered by restrictions, limitations, and unpredictability during the pandemic. However, digital technology has aided in breaking down those barriers. What once seemed difficult, if not impossible, is now attainable. Governments, private institutions, and various global stakeholders from 21 countries shared experiences in managing crises through digital diplomacy during the pandemic (Indonesia Ministry of Foreign Affairs, 2021). An overview of the increasing awareness of the Indonesian government in utilizing digital diplomacy can be analyzed based on Table 1 below.

Table 1: Indonesia Digital Diplomacy Index 2021

\begin{tabular}{|l|l|}
\hline \multicolumn{2}{|c|}{ Indonesia Digital Diplomacy Index Components } \\
\hline $\begin{array}{l}\text { Diplomatic network reach } \\
\text { (Total followers of the diplomatic accounts of each country) }\end{array}$ & $16.8 \mathrm{M}$ (followers) \\
\hline $\begin{array}{l}\text { Diplomatic weight } \\
\text { (Total mentions of a country by other G20 countries diplomatic } \\
\text { networks) }\end{array}$ & 162 mentions \\
\hline $\begin{array}{l}\text { Global country visibility } \\
\text { (Total mentions of a country in worldwide Twitter conversations) }\end{array}$ & $1.86 \mathrm{~K}$ (likes \& retweets) \\
\hline $\begin{array}{l}\text { Message Efficiency } \\
\text { (Average number of likes and retweets per tweet published by a } \\
\text { country's diplomatic network) }\end{array}$ & 8.53 tweets/month \\
\hline $\begin{array}{l}\text { Vocality } \\
\text { (Average daily number of tweets published by a country's diplomatic } \\
\text { network) }\end{array}$ & $3.80 / 10$ \\
\hline $\begin{array}{l}\text { Diplomatic centrality } \\
\text { (Level of overlap between the followers of a country's diplomatic } \\
\text { network and those of other G20 countries diplomatic networks) }\end{array}$ & $+191 \mathrm{~K}$ (followers) \\
\hline $\begin{array}{l}\text { Momentum } \\
\text { (Total number of new followers gained by a country's diplomatic } \\
\text { network over the last 30 days) }\end{array}$ & $\begin{array}{l}\text { Format Proficiency } \\
\text { (Ratio of tweets containing visuals or videos in the total number of } \\
\text { tweets published by a country's diplomatic network) }\end{array}$ \\
\hline
\end{tabular}

Source: Author's work

The Digital Diplomacy Index (DDI) is a characteristic of the digital diplomacy influence toward the G20 countries. Influence indicators are based on data obtained from Twitter social media (DDI, 2021). From this data, we can see that digital diplomacy can reach networks faster than traditional diplomacy.

At the International Conference on Digital Diplomacy (ICDD) meeting in 2021, all participating countries believed that digital diplomacy is urgently needed for crisis management in natural disasters or national health emergencies that are currently engulfing the world. Digital diplomacy requires cyber security, data privacy, and proper internet governance to create a trusted digital diplomacy environment. In an era where Big Techs such as Google and Facebook hold too much data and are too difficult to control, creating a trusted atmosphere and digital diplomacy ecosystem is a complicated and challenging task.

At the same meeting, Indonesia's foreign 
minister said that digital diplomacy is urgent to be optimized. But that does not mean digital diplomacy is without obstacles in its implementation. Cybersecurity, for example, is one of the obstacles that are often discussed related to the effectiveness of digital diplomacy. There are still many countries that do not have high-level cybersecurity systems to ward off data leaks and hacks. This issue is certainly an important thought because diplomacy is an activity that is often confidential.

Digital diplomacy activities carried out by the Indonesian Permanent Mission to the United Nations include teleworking such as video conference coordination meetings discussing reports on the development of COVID-19 in New York City and the condition of Indonesian citizens there. In other words, Indonesia has utilized digital technology to improve services and protection for Indonesian citizens abroad and to respond to various challenges in contemporary international relations (Anshori, 2020).

Optimization of social media in promoting foreign policy, including in the context of branding Indonesia as a country with great economic potential. Carrying out national branding techniques is still a new phenomenon, but is growing in frequency due to the increasingly fierce global competition faced by countries today, both in the domestic and external markets.

In the early days of the COVID-19 pandemic digital diplomacy was focused on efforts to build a positive image to overseas partners about how to handle COVID-19 in Indonesia. The goal is to maintain confidence, especially in foreign investors, in market stability in Indonesia. In addition, branding as a country that is capable in the global virus problem is needed by Indonesia to gain the trust of the World Health Organization (WHO) to obtain vaccine quotas. In addition, Indonesia's need for foreign assistance to procure masks, covid test tools, and various equipment related to other COVID-19 countermeasures needs.

The level of awareness of countries continues to improve in carrying out national branding to promote their country and fulfill three main objectives: attracting tourists, stimulating inward investment, and increasing exports. Indonesia's diplomacy is related to these three things considering the increasingly fierce competition between countries in the current international relations system, which is increasingly showing signs of deglobalization. Digital diplomacy carried out by Indonesian diplomats to penetrate the global market will be even more challenging (Dinnie, 2008).

In achieving economic interests, digital diplomacy methods are also applied. Indonesia implemented new strategies of economic diplomacy in coffee exports to Russia during the pandemic, such as the use of virtual meetings, mobilizing more coffee exporters, and involving the role of the Indonesian embassy in Moscow. The lockdown policies of the Indonesian and Russian governments also make it difficult for both sides to make business visits. Therefore, virtual business meetings are beneficial in providing opportunities for entrepreneurs from both countries to continue to carry out coffee export and import activities in the pandemic period (Madu and Kurniawati, 2021).

The pandemic has changed many people's habits, including economic transactions. Businesses must force themselves to change, accommodate transactions digitally, without physical meetings so that their business can continue to run. The United States Agency for International Development for Inclusive Growth through Innovation, Trade and E-Commerce (USAID IGNITE) in August 2020 issued a Factsheet. The report stated that the digital economy of ASEAN countries has tripled and accounted for 7 percent of ASEAN's gross domestic product (GDP), which reached US\$2.8 trillion. Forms of services that have increased drastically, such as e-commerce, inter-services, and online payments, recorded significant increases. Although the economy is declining due to pandemics, this trend is a concrete example of the community's response in the face of pandemics that need the attention of policymakers. This trend opens up opportunities for ASEAN cooperation and investment with partner countries.

In the end, digital diplomacy has become unavoidable from the efforts of Indonesian representatives in the country to fulfill national interests. The COVID-19 pandemic has hit the world economy, including well-developed countries. Indonesia also experiencing a decline in GDP. The Indonesian Embassy and the Indonesian Consulate General try to carry out their duties and functions, especially in the 
economic field, in a way that has never been done before.

For example, what was done by the Consulate General of the Republic of Indonesia for Ho Chi Minh, Vietnam. in order to connect business people and investors, they do it digitally. Namely through the webinar "Indonesia-Vietnam Business Opportunities to Accelerate Economic Recovery: Creative Economy and Digital Economy, which will be held in November 2021.

COVID-19 has a positive impact in driving the digital economy as it becomes a catalyst for consumers to migrate to digital platforms. Indonesia is a country with a large digital economy market potential seen from the number of internet users in Indonesia as 2 to 2.6 million people with the value of digital trade transactions reaching more than 18 million US Dollar in 2020 and continues to increase by 23.5 million US Dollar in 2021. Consulate General Ho Chi Minh issued a monthly Business communication media that presents the latest developments from Indonesia as well as light information about tourism and articles about the work of Indonesian businesses in Vietnam (Indonesia Ministry of Foreign Affairs, 2021).

Indonesia has a variety of excellent export products that certainly need to be supported in the context of export market expansion. Diplomatic support is not only intended for products from large companies, but also from the Micro, Small and Medium Enterprises (MSMEs) sector. The efforts to facilitate various stakeholders or business actors are carried out in innovative ways, such as online business matching between regional business actors and prospective foreign buyers, virtual exhibitions, cooperation in the utilization of e-marketplace applications, and bringing together national startups with venture capitalists in the region.

The initiative of Indonesian representatives in the Asia Pacific and Africa to support business promotion is also strongly encouraged. One of them is through the establishment of digital platforms, including IDNStore (PRC), Jaipong (Japan), Inquire.id (Malaysia), Indonesiastore.sg (Singapore), and Tradeinamasr.com (Egypt). Support for the development of the creative economy, such as Batik promotion, was also carried out, among others, by Indonesian representatives in Seoul (Directorate General of ASEAN Cooperation, 2021).

The rapid development of digital cooperation is the new face of communicating and negotiating between cross-country actors that stood out in the COVID-19 pandemic. As discussed earlier, pandemics have dragged us into the digital space even to all country's vital sectors. So we can't avoid this change. But what needs to be underlined is that digital diplomacy cannot replace face-to-face or traditional diplomacy. Specifically, in terms of economic negotiations, convincing investors and making agreements requires field surveys and intense in-person meetings.

Various digital diplomacy steps taken by Indonesia in adapting to the changing nature of the world caused by this pandemic are felt to be increasing. However, it looks like everyone is busy innovating independently, looking for steps to survive. This is understandable because many other countries have drawn a roadmap for their digital foreign policy. So that the choice of actions taken will be more focused when facing a crisis like today.

\section{CONCLUSION}

Since COVID-19 hit the world, digital diplomacy has increased because there is no choice but to rely on technology in interacting with other nations. By carrying out digital diplomacy, leaders and diplomats do not need to attend international meetings because they can send pre-recorded speeches or deliver them virtually.

However, the acceleration of the use of digital diplomacy should not ignore security and ethical aspects, especially with stakeholders other than traditional diplomacy actors. For this reason, it is vital to create a trusted digital diplomacy environment. Several steps are recommended. First, creating transparency and initial agreement on the security and privacy of data from each meeting. Second, reducing the gap in digital diplomacy between countries. The adaptive power of each country is different from this digital transition of diplomacy. Third, recognizing the importance of using digital diplomacy to address global issues.

From the results and discussion above, it can be concluded that during the global COVID-19 pandemic, the Indonesian government has maximized various forms of digital diplomacy to gather information, negotiate and respond to vital issues of national interest. Secondly, the study concluded that Indonesia does not have a 
clear agenda or blueprint for using digital diplomacy. Although the use of information technology to publish policies during the COVID19 pandemic is increasing, Indonesia must continue to learn from many countries in introducing the formulation of a digital diplomacy agenda from institutional adaptation to new approaches in foreign policy socialization through new media.

In the future, we may be able to use virtual reality to visit conflict zones or see the devastation caused by climate change to help understand the situation on the ground. The use of digital technology should be enhanced in exploring the use of artificial intelligence to help analyze data such as trade patterns, foreign policy, and gather information from around the world to create more responsive and informative foreign policy decision-making.

\section{REFERENCES}

Abduazimov, M. (2021). Inside Diplomacy during the Pandemic: Change in the Means and Ways of Practice. Indonesian Quarterly, 49(1), 50-66.

Alhashimi, H., Fiallo, A., Freckleton, T. Khalil., M. Mulachela, V and Viera, J (2021). The Future of Diplomacy After COVID-19:

Multilateralism and the Global Pandemic. New York: Routledge. https://doi.org/10.4324/9781003166801

André Barrinha \& Thomas Renard (2017) Cyberdiplomacy: the making of an international society in the digital age, Global Affairs, 3:4$5,353-364$. https://doi.org/10.1080/23340460.2017.141 4924

Anshori, M. F. (2020). Diplomasi Digital Sebagai Dampak Pandemi Global COVID-19: Studi Kasus Diplomasi Indonesia Di Perserikatan Bangsa-Bangsa (Pbb). Mandala: Jurnal Ilmu Hubungan Internasional, 3(1), 100-119. Http://Dx.Doi.Org/10.33822/Mjihi.V3i1.1940

Asadi, A. (2017). A Role of Digital Media on Discussing about the Diplomacy in the World. Open Journal of Political Science, 7, 267-275. https://doi.org/10.4236/ojps.2017.71021

Ashish Sharma \& Varsha Sisodia (2021) Digital diplomacy and the global pandemic, Media Asia. https://doi.org/10.1080/01296612.2021.197 3324

Bjola, Corneliu and Holmes, Marcus (2015). Digital Diplomacy: Theory and Practice. New York: Routledge.

Bull, H. (1997/2002). The anarchical society: A study of order in world politics (3rd ed.). Basingstoke: Palgrave. P.165.

Copeland, D. (2015). Digital technology. In A. F. Cooper, J. Heine, \& R. Thakur (Eds.), The Oxford handbook of modern diplomacy (pp. 453-472). Oxford: OUP.

DDI, Digital Diplomacy Index, 2021. Retrieved from https://digital-diplomacyindex.com/?country=indonesia

Dinnie, Keith. (2008). Nation Branding: Concepts, Issues, and Practice. Elsevier Butterworth-Heunemann.

Directorate General of ASEAN Cooperation. (2021, Agustus, Edition 28). Masyarakat ASEAN: Creative and Digital Economy.

Fletcher, T. (2016). Naked diplomacy: Power and statecraft in the digital age. London: William Collins.

Hocking, B., Melissen, J. (2015). Diplomacy in the digital age. The Hague: Clingendael Institute.

IMF (2020), Fiscal Monitor, retrieved from https://www.imf.org/en/Publications/FM/Iss ues/2020/09/30/october-2020-fiscalmonitor

Luerdi, L. (2021) "Paradiplomacy Of Indonesian Sub-State Actor: Digital Diplomacy of Jakarta Government In Response To COVID19", Berumpun: International Journal of Social, Politics, and Humanities, 4(2), pp. 104-126. doi: 10.33019/berumpun.v4i2.59.

Madu, L., \& Kurniawati, E. (2021, October). Economic Diplomacy Strategies to Increase Indonesian Coffee Exports to Russia in Pandemic Times. In RSF Conference Series: Business, Management and Social Sciences (Vol. 1, No. 4, pp. 92-97) . https://doi.org/10.18196/hi.71121

Ministry of Foreign Affairs of The Republic of Indonesia. (2019, September 10). Indonesia Calls for Digital Diplomacy in the Region. Retrieved from https://kemlu.go.id/portal/en/read/584/view /indonesia-calls-for-digital-diplomacy-inthe-region 
Ministry of Foreign Affairs of The Republic of Indonesia. (2021, November 5). International Conference on Digital Diplomacy. Retrieved from https://kemlu.go.id/portal/en/read/3125/ber ita/international-conference-on-digitaldiplomacy

Ministry of Foreign Affairs of The Republic of Indonesia. (2021, November 25). Pandemi menjadi Katalisator Ekonomi Digital. Retrieved from https://kemlu.go.id/portal/id/read/3194/ber ita/pandemi-menjadi-katalisator-ekonomidigital

Olubukola S. Adesina. (2017). Foreign policy in an era of digital diplomacy, Cogent Social Sciences, 3:1, 1297175. https://doi.org/10.1080/23311886.2017.129 7175

Purwasito, A., \& Kartinawati, E. (2020, December). Hybrid Space and Digital Diplomacy in Global Pandemic COVID-19. In 6th International Conference on Social and Political Sciences (ICOSAPS 2020) (pp. 662666). Atlantis Press. https://dx.doi.org/10.2991/assehr.k.201219. 100

Sandre, Andreas (2015). Digital Diplomacy: Conversations on Innovation in Foreign Policy. London: Rowman \& Littlefield.

Syaifani, S., \& Qubba, N. R. (2017). Joko Widodo's digital diplomacy: A prospect and challenge for Indonesia's digital diplomacy towards middle power. Jurnal Hubungan Internasional, 10(2), 106-117.

Yahya, T. (2016, April 22). Digital Diplomasi, Sebuah Kebutuhan Mendesak. Retrieved from https://news.detik.com/kolom/d3194614/digital-diplomacy-sebuahkebutuhan-mendesak

Yasmin, N. (2019, September 10). Foreign Ministry Step Up Game in Digital Diplomacy. Retrieved from https://jakartaglobe.id/news/foreignministry-steps-up-game-in-digitaldiplomacy/

\section{ABOUT THE AUTHOR}

Dewi Triwahyuni, email: dewi.triwahyuni@email.unikom.ac.id

Dewi Triwahyuni, Program Studi Ilmu Hubungan Internasional, Universitas Komputer Indonesia, Bandung, Indonesia. 